\title{
Anatomically-preserved cordaitalean trees from Lower Pennsylvanian (Langsettian) dryland alluvial-plain deposits at Joggins, Nova Scotia
}

\author{
HowARD J. FALCON-LANG \\ Department of Earth Sciences, University of Bristol, Bristol BS8 1RJ, United Kingdom \\ $<$ howard.falcon-lang@bristol.ac.uk>
}

Date received:February 26, 2004 Date accepted:May 24, 2004

\begin{abstract}
Recent discoveries at Joggins, Nova Scotia have altered our understanding of the Pennsylvanian tropical biome. Of particular significance has been the recognition of seasonal dryland ecosystems, compositionally distinct from the peatforming wetland rainforests. Here I describe two anatomically-preserved fossil plant specimens from dryland alluvial plain facies. The first specimen, Mesoxylon cf. sutcliffi, is previously unknown from Joggins. It is a septate cordaitalean axis with mesarch leaf traces and a non-sympodial vasculature. Where found as isolated blocks, the secondary xylem of this plant has previously been classified as Dadoxylon recentium. The axis exhibits subtle growth interruptions suggestive of tropical rainfall seasonality, while associated traumatic zones may record fire-damage. The second specimen is a Dadoxylon stump rooted within well-drained floodbasin soils. It confirms earlier conjecture, based on parautochthonous assemblages, that cordaitalean trees grew in inter-channel areas. Together these new specimens improve our knowledge of the composition and ecology of seasonal dryland vegetation at Joggins.
\end{abstract}

\section{RÉSUMÉ}

Des découvertes récentes à Joggins (Nouvelle-Écosse), ont modifié notre compréhension du biome tropical pennsylvanien. La reconnaissance d'écosystèmes de milieux arides saisonniers aux compositions distinctes des forêts tropicales humides ayant formé des tourbières, s'avère particulièrement importante. Je décris aux présentes deux spécimens préservés de plantes fossiles anatomiquement provenant du faciès d'une plaine alluviale de milieu aride. Le premier spécimen, un Mesoxylon cf. sutcliffi, était auparavant inconnu à Joggins. Il s'agit d'un axe cordaitaléen cloisonné comportant des cicatrices foliaires à arc moyen et une vasculature non sympodiale. Lors de sa découverte sous forme de blocs isolés, on avait précédemment classifié le xylème secondaire de cette plante en tant que Dadoxylon recentium. L'axe présente des interruptions de croissance subtiles évoquant des chutes de pluie tropicales saisonnières, tandis que les cernes traumatiques associés pourraient témoigner de dommages causés par le feu. Le second spécimen est une souche de Dadoxylon qui plongeait ses racines à l'intérieur des sols d'un bassin de crue bien drainé. Il confirme une conjecture antérieure, basée sur des assemblages parautochtones, supposant que les arbres cordaitaléens aient poussé dans des secteurs situés entre des chenaux. Ces deux nouveaux spécimens améliorent notre connaissance de la composition et de l'écologie de la végétation saisonnière des milieux arides à Joggins.

[Traduit par la rédaction.]

\section{INTRODUCTION}

Continental red-bed intervals comprise a significant proportion of the classic Lower Pennsylvanian (Langsettian) section at Joggins, Nova Scotia (Fig. 1; Calder 1998). These units were formed in a well-drained alluvial plain environment subject to seasonal tropical rainfall (Davies and Gibling 2003). Seasonal dryland environments were apparently colonised by ecologically stressed, fire-prone vegetation dominated by cordaitaleans and medullosan pteridosperms (Falcon-Lang 2003a, 2003b), and additionally supported a low-diversity fauna of invertebrates and tetrapods (Hebert and Calder 2004; Falcon-Lang et al. 2004).

A high proportion of fossil plant material in Joggins alluvial plain deposits exhibits excellent cellular preservation as either calcite-permineralisations or wildfire-produced charcoal (Falcon-Lang 2003b). The common occurrence of these two preservational modes is, of course, closely related to the depositional environment: production of carbonate-charged groundwater is promoted in well-drained, seasonally dry environments (Goudie 1983), while such settings also promote a relatively high fire frequency (Chandler et al. 1983). 
Calcite-permineralized and charred plant remains so far reported from the alluvial plain deposits comprise three morphotaxa of pycnoxylic gymnosperm wood, Dadoxylon acadianum, Dadoxylon materiarium and Dadoxylon recentium. The first two taxa are unequivocally cordaitalean because they occur in biological connection with Artisia transversa. The affinity of Dadoxylon recentium has been considered enigmatic (FalconLang 2003a, 2003b; Falcon-Lang et al. 2004). In this paper two new and important discoveries of calcite-permineralised specimens from alluvial plain deposits at Joggins are described. These specimens improve our knowledge of the composition and ecology of dryland vegetation ecosystems, and clarify the identity of the previously enigmatic Dadoxylon recentium.

\section{NEW DISCOVERIES}

The two new specimens were collected within a detailed sedimentary facies context at Joggins during August 2003 (Fig. 2). Standard, unstained thin sections were prepared along radial longitudinal (RLS), tangential longitudinal (TLS), and transverse sections (TS), and studied with an Olympus BH-5 binocular microscope. The specimens, together with accompanying thin sections, are deposited in the Nova Scotia Museum of Natural History, Halifax, and have accession numbers with the prefix NSM.

\section{Permineralized axis}

\section{Specimen: NSM004GF013.001 (Figs. 3-4)}

Description: The first specimen is an unbranched woody axis, $18-26 \mathrm{~mm}$ in diameter, with a preserved length of $19 \mathrm{~cm}$. It

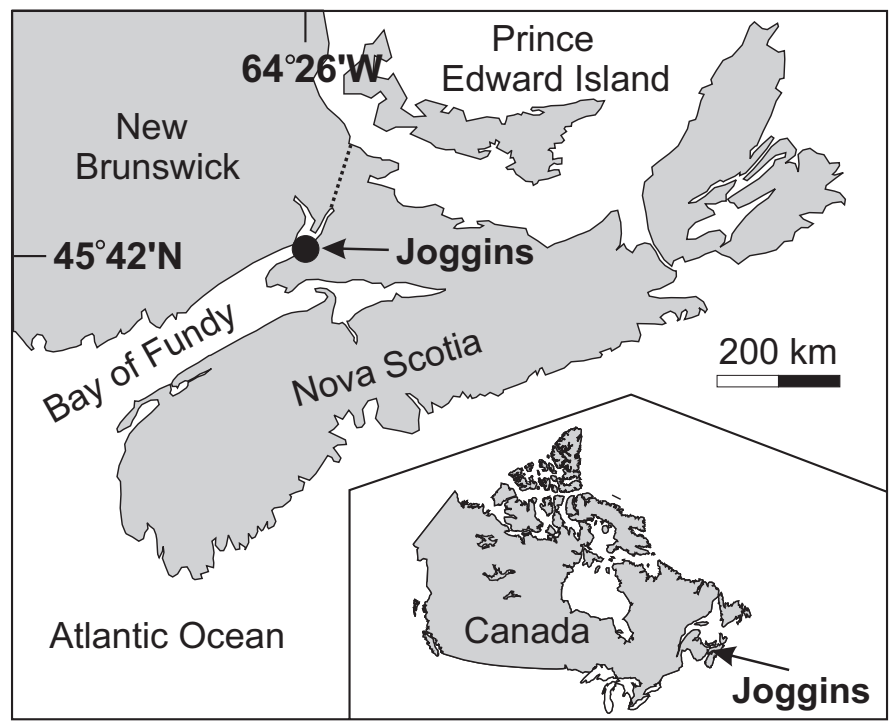

Fig. 1 Location details of the classic Joggins section on Chignecto Bay, Nova Scotia, Canada (latitude $45^{\circ} 42^{\prime} \mathrm{N}$; longitude $\left.64^{\circ} 26^{\prime} \mathrm{W}\right)$. was located within a fine- to medium-grained, multistorey channel body at $138 \mathrm{~m}$ in the section of Davies and Gibling (2003). The specimen lay prostrate in lag deposits at the base of the second channel storey, together with abundant indeterminate woody material, much of it preserved as charcoal. Given its facies context the studied specimen is clearly allochthonous. It is unclear whether this axis was permineralized at a different site and subsequently reworked into the channel, or whether permineralization took place in the host channel itself. However, given that permineralized cordaitalean wood is mostly restricted to the well-drained alluvial plain association at Joggins (Falcon-Lang 2003b), it is a reasonable inference that the allochthonous axis described in this paper originated within the seasonal dryland environment in general.

The specimen exhibits exceptional anatomical preservation permitting a very detailed description. The axis, which is partially flattened, probably as a result of sediment compaction, has a total diameter of $18-26 \mathrm{~mm}$. It consists of a central parenchymatous pith, 7.1-13.3 mm in diameter, surrounded by a pycnoxylic xylem cylinder, 5.1-6.9 mm wide (Fig. 3A). A small amount of extraxylary tissue adheres to the outer margin
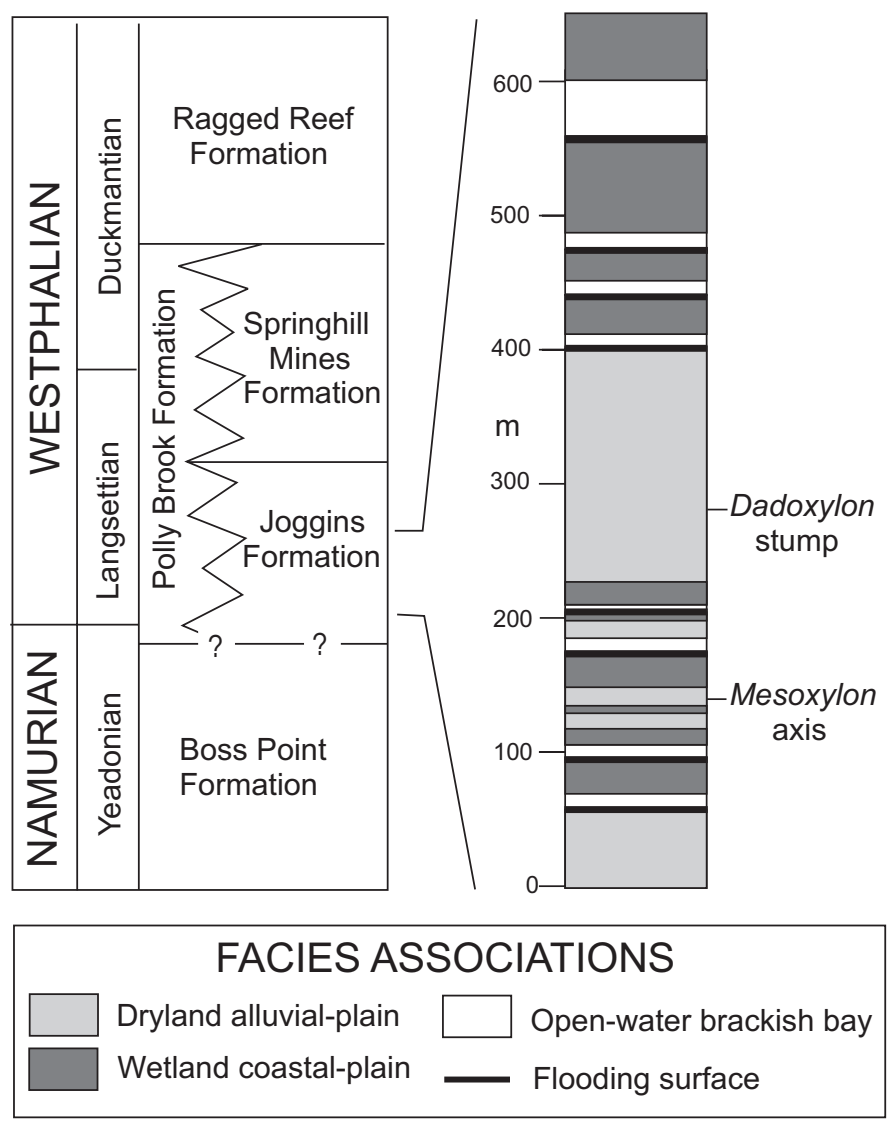

Fig. 2 Geological context of Joggins section. Stratigraphy of the Pennsylvanian Cumberland Group (after Ryan et al. 1991) with a schematic log of the central $600 \mathrm{~m}$ thick part of the Joggins Formation (after Davies and Gibling 2003). Position of the two new specimens are shown. 
of the axis in one region, but is too poorly preserved to warrant description.

The pith is septate with horizontal diaphragms spaced 1.4-2.3 mm apart (Fig. 3B). At the margins of the pith, tissue consists of vertically-oriented, rectangular, resin-filled parenchyma (70-80 $\mu \mathrm{m}$ high, 20-30 $\mu \mathrm{m}$ wide) (Fig. 4A-D). Similar, horizontally-orientated parenchyma or larger (up $110 \mu \mathrm{m}$ diameter), irregular parenchyma compose the septa.

The primary vasculature is non-sympodial, and primary xylem only occurs as the downward extension of mesarch leaf traces (Fig. 4A). In TS, leaf traces adjacent to the pith are clearly paired (Fig. 4B), and when followed down the stem axis, fuse into a single trace. Leaf traces are helically arranged, and after branching, depart from the margin of the pith at an initial angle of $30-40^{\circ}$ from the vertical, before becoming subhorizontal in the secondary xylem (Fig. 4D). They are typically 210-300 $\mu \mathrm{m}$ in diameter, contain protoxylem and metaxylem, and over their lower surface are continuous with the secondary xylem. In proximal regions, a layer of profusely pitted parenchyma, continuous with the pith, covers the upper surface of the leaf trace (Fig. 4D-E). Protoxylem tracheids, 6-12 $\mu \mathrm{m}$ in diameter, are characterised by annular and spiral thickening with scalariform and transitional pitting seen on the 9-15 $\mu \mathrm{m}$ diameter metaxylem tracheids (Fig. 4C, F).

Secondary xylem is composed of densely arranged tracheids cells typical of coniferopsids (i.e. pycnoxylic). Tracheids, 12-36 $\mu \mathrm{m}$ in diameter, are characterised by 1-2-seriate, contiguous, alternate, bordered pitting on their radial walls (Fig. 4H). Bordered pits are circular to hexagonal $(11 \mu \mathrm{m})$ with circular to slit-like, crossed apertures $(4-5 \mu \mathrm{m})$. Tangential tracheid walls are unpitted. Rays are exclusively uniseriate, $1-8$ cells high (mode: 1-2), up to $1.35 \mathrm{~mm}$ long, and locally continuous with the pith (Fig. 4G). They are composed of rectangular parenchyma cells $(12-21 \mu \mathrm{m}$ wide, $24-35 \mu \mathrm{m}$ high, $42-63 \mu \mathrm{m}$ long) which exhibit 1-6 araucarioid pits ( $5 \mu \mathrm{m}$ diameter $)$ in each cross-field (Fig. 4I). Viewed in TS, tracheids are arranged in files of interspersed wide $(29 \mu \mathrm{m})$ and narrow $(10 \mu \mathrm{m})$ cells as seen in extant Ginkgo (Srivastava 1963) (Fig. 4J-K).

Growth rings are absent (Fig. 4J); however, two extremely weak growth interruptions characterised by diffuse zones of 12-18 $\mu \mathrm{m}$ diameter tracheids are present (Figs. 3A, 4K). Locally associated with one growth interruption are small zones of traumatic tissue. These contain irregularly spaced tracheids, and resin-filled, profusely-pitted parenchyma (Fig. 4L). A zone of tracheid cells with opaque cell walls in this region may suggest that part of the surface of the growth interruption was partially charred.

Interpretation: This specimen is cordaitalean as indicated by its septate pith. In the past, two types of cordaitalean axis have been identified. Axes showing endarch maturation and a sympodial vasculature have been classified as Cordaixylon, while those with mesarch leaf traces and a non-sympodial
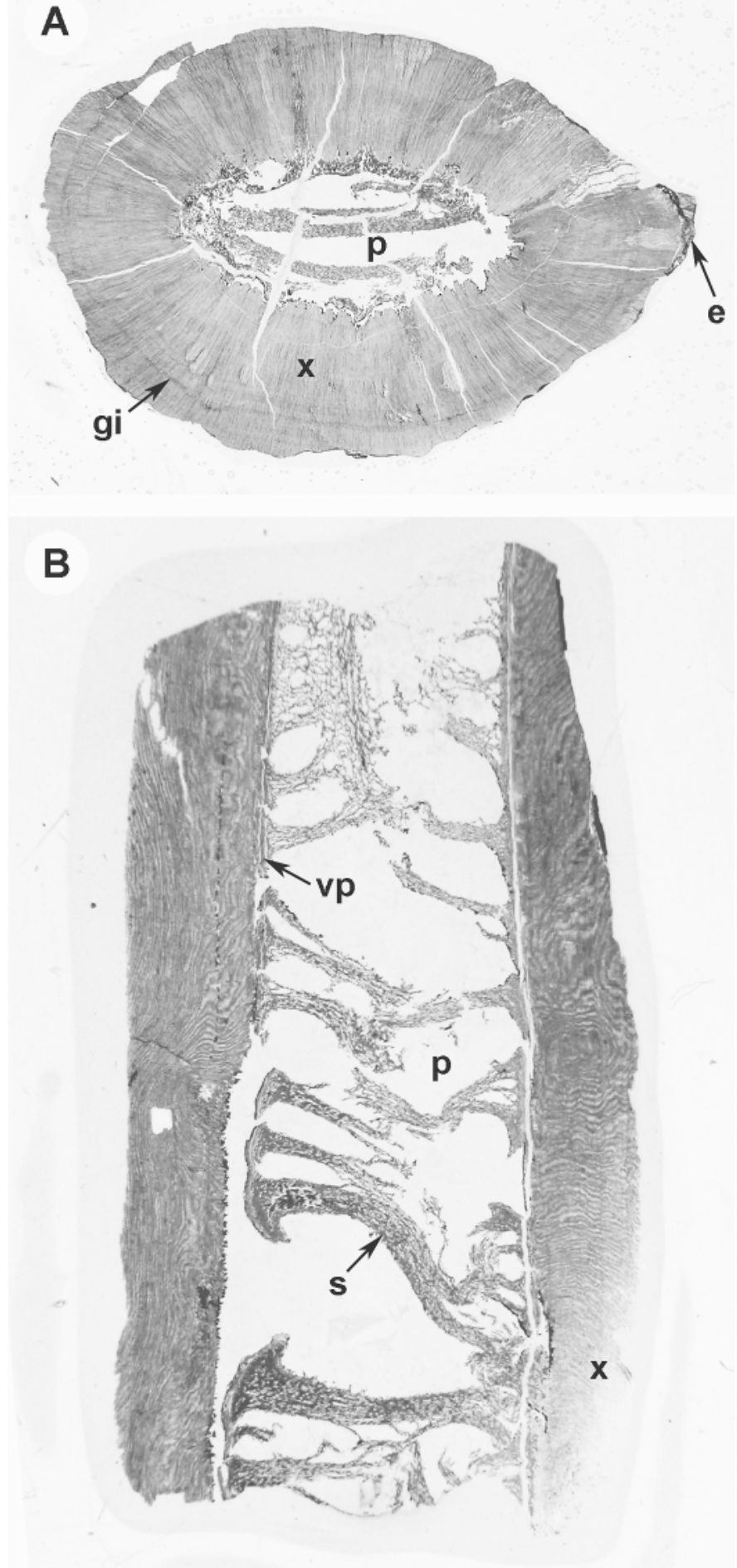

Fig. 3 General characteristics of Mesoxylon cf. sutcliffi, NSM004GF013.001. A: Axis with septate pith and xylem cylinder, TS, x3. B: Axis showing pith diaphragms, RLS, x3. Explanation of abbreviations as follows: $p$, pith; $x$, secondary xylem; gi, growth interruption; e, extraxylary tissue; vp, vertical, resin-filled parenchyma; s, horizontal septa. 


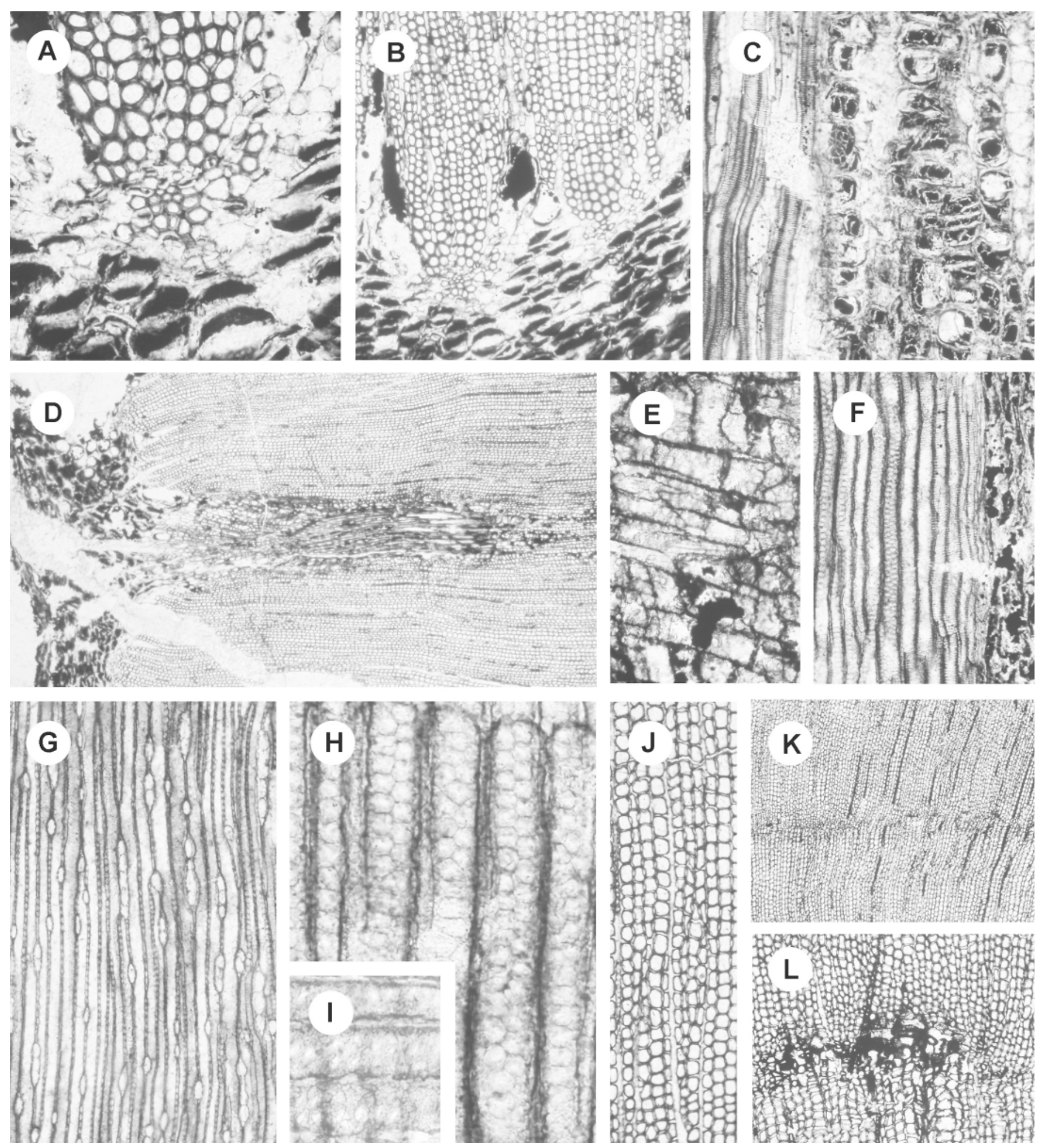

Fig. 4 Anatomy of Mesoxylon cf. sutcliffi, NSM004GF013.001. A: Mesarch leaf trace, TS, x300. B: Paired mesarch leaf traces which fuse down the axis, TS, x120. C: Leaf trace with annular and spiral thickening adjacent to pith showing resin-filled parenchyma, RLS, x120. D: Sub-horizontal leaf trace in secondary xylem, TS, x30. E: Extension of pith overlying proximal leaf trace, TS, x350. F: Leaf trace showing transition from annular protoxylem to secondary xylem with bordered pits, RLS, x120. G: Short, uniseriate rays in secondary xylem, TLS, x90. H: 1-2-seriate bordered pits in secondary xylem, RLS, x500. I: 2-4 araucarioid crossfield pits, RLS. J: Secondary xylem, TS, x500. K: Growth interruption in secondary xylem, TS, x90. L: Traumatic tissue associated with growth interruption, TS, x70. 
vasculature, as seen in the Joggins specimen (Fig. 4A), are classified in the genus Mesoxylon (Scott and Maslen 1910; Trivett and Rothwell 1985). However, discoveries of axes with intermediate and overlapping characters has precipitated a crisis in traditional cordaitalean taxonomy (Trivett and Rothwell 1988, 1991). Nevertheless, as no unified taxonomic system has yet arisen to properly characterise contemporary knowledge of cordaitalean diversity (Trivett and Rothwell 1991), the traditional generic concepts of Mesoxylon and Cordaixylon currently remain acceptable.

The Joggins specimen is closely similar to, if not identical with, Mesoxylon sutcliffi ifrom Marsdenian-Langsettian marine roof shales in northern England (Scott and Maslen 1910; Maslen 1911; Scott et al. 1997). However, given that extraxylary tissue, a key feature of the Mesoxylon sutcliffi concept, is not well-preserved in the Joggins specimen (Fig. 3A), this taxonomic assignment is made with reservation. Specimens of Dadoxylon recentium described from alluvial plain units at Joggins (Falcon-Lang 2003b) are identical to the secondary xylem of Mesoxylon cf. sutcliffi, and consequently, most, if not all, wood of this type at Joggins is cordaitalean.

\section{Permineralized stump}

\section{Specimen: NSM004GF013.002 (Fig. 5)}

Description: The second specimen is a woody tree stump preserved in growth position. It occurs within a 7-m-thick succession of fine-grained sheet sandstone beds between 276-283 $m$ in section of Davies and Gibling (2003). This interval lies a few metres below the 'Hebert beds' recently described as a seasonal dryland waterhole deposit (Falcon-Lang et al. 2004; Hebert and Calder 2004). The stump is rooted in thin red/grey mudstone beds between individual sheet sandstone units, and overlain by fine-grained sandstone. Specifically, it is located at the base of the cliff line, where it is partially buried by talus deposits (Fig. 5).

The stump is $17 \mathrm{~cm}$ in diameter above its flared base and has a preserved height of $11 \mathrm{~cm}$. Most of the stump has evidently rotted away, resulting in a wide, irregular, central cavity infilled by fine-grained sandstone and siltstone. The stump outline is defined by a very thick (up to $7 \mathrm{~cm}$ wide) organic rind which preserves several narrow, radially-orientated, buttresses on the external surface. Although mostly coalified, isolated patches of the stump have been calcite-permineralized and retain poorly preserved anatomical details.

Interpretation: Preserved detail is sufficient to identify the material as pycnoxylic gymnosperm wood of Dadoxylon-type, the preserved rind comprising the secondary xylem cylinder, and the central void, marking the probable position of the decay-expanded pith. Given that all three species of Dadoxylon known from Joggins (Falcon-Lang 2003b) are now considered to be the cordaitalean woods, the fossil stump represents the first cordaitalean tree found in growth position at Joggins.

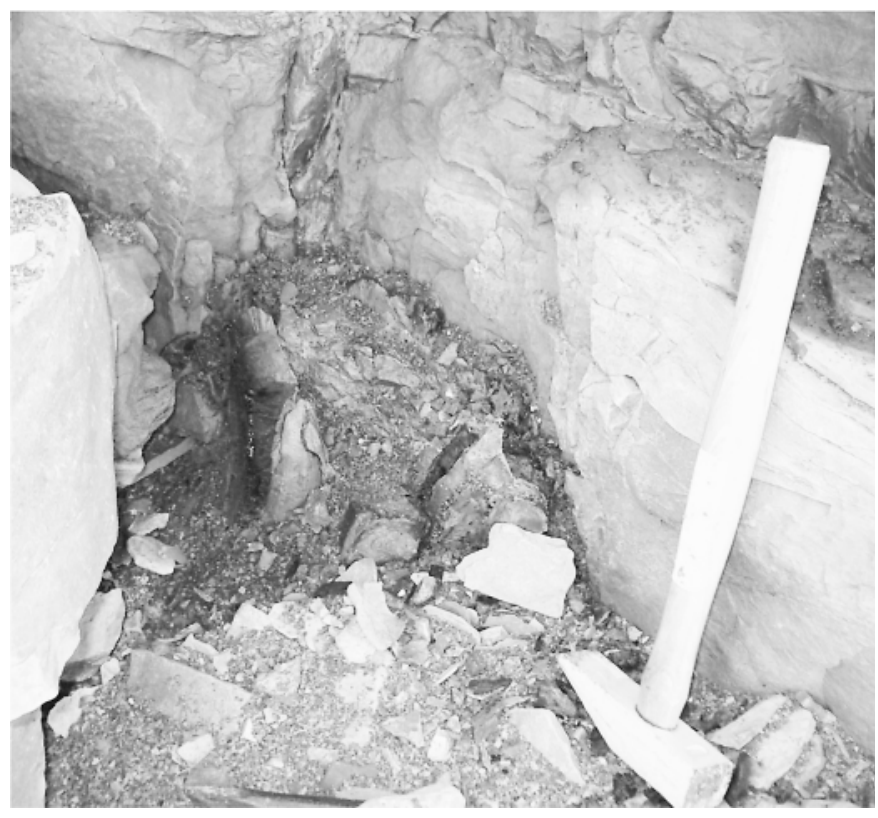

Fig. 5 Photograph of poorly preserved Dadoxylon stump, NSM004GF013.002, scale: hammer is $38 \mathrm{~cm}$ long.

\section{DISCUSSION}

The two discoveries of anatomically preserved cordaitaleans shed new light on the composition and ecology of the Joggins alluvial-plain environment. First of all, the occurrence of a cordaitalean stump in growth position confirms that welldrained alluvial soils supported cordaitalean trees; previously, this had only been inferred on the basis of parautochthonous assemblages (Falcon-Lang 2003b; Falcon-Lang et al. 2004). With the possible exception of Stephanian examples in France (Grand'Eury 1877), this specimen is the first cordaitalean tree in growth position discovered outside peat mire environments. Biomechanical relationships between tree basal diameter and height (Niklas 1994) indicate that the stump was part of a small- to medium-sized tree with a maximum buckling height of only $15 \mathrm{~m}$.

The other specimen, Mesoxylon cf. sutcliffi, further expands our knowledge of the diversity of alluvial-plain cordaitalean communities. The occurrence of three distinct types of secondary xylem indicates that several cordaitaleans inhabited alluvial-plain environments at Joggins. Cuticular studies of Cordaites leaves from North America and Europe (Simunek 2000; Zodrow et al. 2000) indicate that the taxonomic diversity of this gymnosperm group is generally very poorly understood. Clearly, further work, including cuticular studies of leaves, is needed at Joggins to better characterise alluvial plain cordaitalean communities.

Importantly, the Mesoxylon axis allows inferences to be made about the ecology and environment of alluvial plain settings. The occurrence of weakly developed growth interruptions (sensu Schweingruber 1992) in the secondary xylem cylinder may indicate climatic rhythmicity, such as the occur- 
rence of a tropical dry season (Falcon-Lang et al. 2004; Calder et al. in press). The presence of traumatic tissue associated with the growth interruptions is also significant (Fig. 4L). Such features are caused by frost, fire, or insect attack (Glock et al. 1960; Dechamps 1984). However, given their association with growth interruptions, and the common preservation of plant material as charcoal, these features most likely originated as the down-trunk extensions of fire scars (Dechamps 1984). This interpretation is supported by a localized zone of the growth interruption surface that apparently exhibits partial charring.

The recognition that cordaitalean trees dominated seasonal alluvial plains at Joggins improves our general understanding of this important Late Palaeozoic gymnosperm group. Previous studies have emphasized the local dominance of cordaitaleans in coastal mangrove settings (Cridland 1964), freshwater peat mires (DiMichele and Phillips 1994), upland environments (Falcon-Lang and Bashforth 2004), and outside the tropical zone, in cool temperate environments (DiMichele et al. 2001). The new data from Joggins expands our knowledge of the ecological range of tropical cordaitaleans, proving their existence in seasonal drylands.

In summary, the picture emerging from ongoing discoveries in the red alluvial plain deposits at Joggins is of ecologically stressed, fire-prone gymnosperm-dominated vegetation inhabited by a low-diversity fauna (Falcon-Lang 2003b; Falcon-Lang et al. 2004). This environment markedly contrasts to typical reconstructions of Pennsylvanian tropical wetland rainforests (DiMichele et al. 2001), and demonstrates the wide range of environments and ecosystems that occupied the tropical zone during this time.

\section{ACKNOWLEDGEMENTS}

I gratefully acknowledge receipt of a NERC Fellowship held at the University of Bristol (NER/I/S/2001/00738) and a Palaeontology Grant from the Museum of Nova Scotia (2001). I thank John Calder, Martin Gibling, and Mike Rygel for their encouragement and support in my Joggins endeavours. I thank Miriam Amy for translating parts of Grand'Eury (1877). I thank John Calder and Bob Wagner for their critical reviews of an earlier version of this manuscript.

\section{REFERENCES}

Calder, J.H. 1998. The Carboniferous evolution of Nova Scotia. In Lyell, the Past is the Key to the Present. Edited by D.J. Blundell and A.C. Scott. Geological Society, London, Special Publications, 143, pp. 261-302.

Calder, J.H., Gibling, M.R., Scott, A.C., Hebert, B.L., \& REID, D.R. in press. A fossil lycopsid forest succession in the classic Joggins section of Nova Scotia: palaeoecology of a disturbance-prone Pennsylvanian wetland. In Wetlands through Time. Edited by S.J. Greb and W.A. DiMichele. Geological Society of America, Special Paper.
Chandler, C., Cheney, P., Thomas, P. Trabaud, L., \& WilLIAMS, D. 1983. Fire in Forestry, Volume 1: Forest Fire and Effects. John Wiley \& Sons, New York, New York, 450 p.

Cridland, A.A. 1964. Amyelon in American coal balls. Paleontology, 7, pp. 189-209.

Davies, S.J., \& Gibling, M.R. 2003. Architecture of coastal and alluvial deposits in an extensional basin: the Carboniferous Joggins Formation of eastern Canada. Sedimentology, 50, pp. $415-439$.

Dechamps, R. 1984. Evidence of bush fires during the PlioPleistocene in Africa (Omo and Sahabi) with aid of fossil woods. In Paleoecology of Africa and the Surrounding Islands, Volume 16. Edited by J.A. Coetzee and E.M. Van Zinderen Bakker. A.A. Balkema, Rotterdam, The Netherlands. pp. 232-239.

DiMichele, W.A., \& Phillips, T.L. 1994. Paleobotanical and paleoecological constraints on models of peat formation in the Late Carboniferous of Euramerica. Paleogeography, Paleoclimatology, Paleoecology, 106, pp. 39-90.

DiMichele, W.A., Pfefferkorn, H.W., \& Gastaldo, R.A. 2001. Response of Late Carboniferous and Early Permian plant communities to climate change. Annual Review of Earth and Planetary Sciences, 29, pp. 461-487.

FALCON-LANG, H.J. 2003a. Response of Late Carboniferous tropical vegetation to transgressive-regressive rhythms at Joggins, Nova Scotia. Journal of the Geological Society, London, 160, pp. 643-647.

FALCON-LANG, H.J. 2003b. Late Carboniferous tropical dryland vegetation in an alluvial plain setting, Joggins, Nova Scotia, Canada. Palaios, 18, pp. 197-211.

Falcon-Lang, H.J., \& Bashforth, A.R. 2004. Pennsylvanian uplands were forested by giant cordaitalean trees. Geology, 32, pp. 417-420.

Falcon-Lang, H.J., Rygel, M., Calder, J.H., \& Gibling, M.R. 2004. An early Pennsylvanian waterhole deposit and its fossil biota in a dryland alluvial plain setting, Joggins, Nova Scotia. Journal of the Geological Society, London, 161, pp. 209-222.

Glock, W.S, Studhalter, R.A., \& Agerter, S.R. 1960. Classification and multiplicity of growth layers in the branches of trees. Smithsonian Miscellaneous Collections, 140. Publication no. 4421, Washington, D.C.

Goudie, A.S. 1983. Calcrete. In Chemical Sediments and Geomorphology. Edited by A.S. Goudie and K. Pye . Academic Press, London, U.K., pp. 93-131.

Grand'Eury, F.C. 1877. Mémoire sur la flore carbonifère du département de la Loire et du centre de la France, étudiée aux trois points de vue botanique, stratigraphique et géognostique. Mémoires de l'Académie des Sciences de l'Institut de France, 24, pp. 1-624.

Hebert, B.L., \& Calder, J.H. 2004. On the discovery of a unique terrestrial faunal assemblage in the classic Pennsylvanian section at Joggins, Nova Scotia. Canadian Journal of Earth Sciences, 41, pp. 247-254.

Maslen, A.J. 1911. The structure of Mesoxylon sutcliffii(Scott). Annals of Botany, 25, pp. 381-414. 
NikLAs, K.J. 1994. Predicting the height of fossil plant remains: an allometric approach to an old problem. American Journal of Botany, 81, pp. 1235-1243.

Ryan, R.J., Boehner, R.C., \& Calder, J.H. 1991. Lithostratigraphic revision of the Upper Carboniferous to Lower Permian strata in the Cumberland Basin, Nova Scotia and the regional implications for the Maritimes Basin in Atlantic Canada. Canadian Society of Petroleum Geologists Bulletin, 39, pp. 289-314.

SCHWEINGRUBER, F.H. 1992. Annual growth rings and growth zones in woody plants in southern Australia. International Association of Wood Anatomists' Bulletin, 13, pp. 359379.

Scott, A.C., Galtier, J., Mapes, R.H., \& Mapes, G. 1997. Palaeoecological and evolutionary significance of anatomically preserved terrestrial plants in Upper Carboniferous marine goniatite bullions. Journal of the Geological Society, London, 154, pp. 61-68.

ScotT, D.H., \& Maslen A.J. 1910. On Mesoxylon, a new genus of Cordaitales - preliminary note. Annals of Botany, 24, pp. 236-239.

Simunek, Z. 2000. Cuticles of Cordaites from the Westphalian, Stephanian and Autunian of the Bohemian Massif (Czech
Republic): a preliminary study. Acta Palaeobotanica, 40, pp. 25-34.

SRIVASTAVA, L.M. 1963. Cambium and vascular derivatives of Ginkgo biloba. Journal of the Arnold Arboretum, 44, pp. 165-192.

Trivett, M.L., \& Rothwell, G.W. 1985. Morphology, systematics, and palaeoecology of Palaeozoic fossil plants: Mesoxylon priapi, sp. nov. (Cordaitales). Systematic Botany, 10, pp. 205-223.

TrivetT, M.L., \& Rothwell, G.W. 1988. Diversity among Paleozoic Cordaitales: The vascular architecture of Mesoxylon birame Baxter. Botanical Gazette, 149, pp. 116-125.

Trivett, M.L., \& Rothwell, G.W. 1991. Diversity among Paleozoic Cordaitales. Neues Jahrbuch für Geologie und Paläontologie, Abhandlungen, 183, pp. 298-305.

Zodrow, E., Simunek, Z., \& Bashforth, A.R. 2000. New cuticular morphotypes of Cordaites principalis from the Canadian Carboniferous Maritimes Basin. Canadian Journal of Botany, 78, pp. 135-148.

Editorial responsibility: Robert A. Fensome 
